\title{
Formation of Ethylene by a Soil Fungus
}

\author{
By J. M. LYNCH AND S. H. T. HARPER \\ Agricultural Research Council, Letcombe Laboratory, Wantage, OXI $29 J T$
}

(Received 22 June 1973)

\begin{abstract}
SUMMARY
Methionine is a substrate for ethylene formation in Mucor hiemalis, but glucose is also required for maximal ethylene production. The formation of ethylene from these substrates in a defined mineral salts medium was studied both with sealed shaken flasks and with a chemostat. Oxygen promoted growth and ethylene production per unit weight of organism. That anaerobic conditions appear to be necessary to observe ethylene accumulation in the soil is probably because soil anaerobiosis mobilizes the substrates required for ethylene biosynthesis.
\end{abstract}

\section{INTRODUCTION}

Earlier work in this laboratory (Smith \& Russell, 1969; Smith \& Restall, 197I; Smith \& Robertson, I97I ; Dowdell, Smith, Crees \& Restall, 1972) showed that ethylene, apparently produced by micro-organisms, occurs in anaerobic soils at concentrations sufficient to affect the growth of cereal roots. The formation of ethylene in plants is well-documented whereas there have been fewer reports concerning its production by micro-organisms. However, Ilag \& Curtis (1968) suggested that ethylene formation might be common amongst the fungi, although only one bacterium, Pseudomonas solanacearum, has been reported to produce ethylene in pure culture (Freebairn \& Buddenhagen, I964; Swanson, Wilkins \& Kennedy, 1972).

Lieberman, Kunishi, Mapson \& Wardale (I966) first showed methionine to be a precursor of ethylene and it is now established as the major if not the sole precursor in higher plants (Baur \& Yang, 1972). Ethionine is also a precursor in a non-enzymatic model system (Lieberman, Kunishi, Mapson \& Wardale, 1965). On the other hand, Wang, Persyn \& Krackov (1962) and Jacobsen \& Wang (1968) suggested that ethylene biosynthesis in Penicillium digitatum is closely associated with the Krebs cycle. Some evidence suggests that ethanol is a precursor of ethylene in P. digitatum (Hall, I95I; Phan, I960).

We have shown that specific substrates are important in ethylene production in the soil; by means of soil enrichment with glucose and methionine it was possible to isolate Mucor hiemalis and two yeasts which produced ethylene in pure culture (Lynch, 1972).

Mucor hiemalis is one of the commonest soil fungi and is a primary colonizer of decaying vegetable matter (Domsch \& Gams, 1972). Thus it seemed that $M$. hiemalis might be a major producer of ethylene in agricultural soils, and accordingly we have studied ethylene production by this organism in relation to soil conditions.

\section{METHODS}

Organism. Mucor hiemalis, isolated from a heavy clay soil (Lynch, 1972).

Culture medium. The following four constituents of the medium were sterilized separately by autoclaving and mixed aseptically. (i) D-glucose ( $5 \mathrm{~g} / \mathrm{l}$ for flask cultures, $9 \mathrm{~g} / \mathrm{l}$ for chemo- 
stat cultures). In flask cultures to investigate the substrates for ethylene biosynthesis, methionine was replaced by other possible precursors at $5 \mathrm{~g} / \mathrm{l}$. (ii) Sodium nitrate $(3.5 \mathrm{~g} / \mathrm{l})$. (iii) Mineral salts mixture consisting of $(\mathrm{g} / \mathrm{l}): \mathrm{MgSO}_{4} \cdot 7 \mathrm{H}_{2} \mathrm{O}, 0.5 ; \mathrm{CaCl}_{2}, 0 \cdot \mathrm{I}$; ferric citrate. $5 \mathrm{H}_{2} \mathrm{O}, 0 . \mathrm{I} ; \mathrm{ZnSO}_{4} \cdot 7 \mathrm{H}_{2} \mathrm{O}, 0.05 ; \mathrm{MnCl}_{2} .4 \mathrm{H}_{2} \mathrm{O}, 0.05 ; \mathrm{CuCl}_{2} .2 \mathrm{H}_{2} \mathrm{O}, 0.005 ; \mathrm{Na}_{2} \mathrm{MoO}_{4} .2 \mathrm{H}_{2} \mathrm{O}$, $0.005 ; \mathrm{Na}_{2} \mathrm{~B}_{4} \mathrm{O}_{7} . \mathrm{I}_{2} \mathrm{H}_{2} \mathrm{O}, 0.002 ; \mathrm{CoCl}_{2} .6 \mathrm{H}_{2} \mathrm{O}, 0.0002$; citric acid, 0.756 ; and $\mathrm{NaOH}, 0.432$. (iv) $\mathrm{KH}_{2} \mathrm{PO}_{4}(5 \mathrm{~g} / \mathrm{l})$ buffer, to give a final $\mathrm{pH}$ in the medium of 6.5 .

Inoculum. Cultures were grown on malt agar for 5 days at $25^{\circ} \mathrm{C}$ in $250 \mathrm{ml}$ conical flasks containing about $30 \mathrm{ml}$ of solid medium. Spores were harvested from these cultures with a sterile aqueous solution $(0.05 \%, \mathrm{w} / \mathrm{v})$ of the wetting agent Manoxol OT (B.D.H. Ltd, Poole, Dorset). The mycelial debris was removed by passing the suspension through a wire filter. A final spore concentration in the medium of at least $10^{4}$ per $\mathrm{ml}$ was used.

Growth in sealed flasks. Flask cultures were made in $100 \mathrm{ml}$ of medium in nephlos flasks $(250 \mathrm{ml}$ conical flasks to which a $20 \mathrm{ml}$ Pyrex test-tube with a $5 \mathrm{~mm}$ diameter had been fused so that a sample from the flask could be decanted into it to measure turbidity). The flasks were fitted with rubber bungs containing two stainless steel tubes ( $3 \mathrm{~mm}$ i.d.) plugged with cotton wool and sealed with rubber serum caps ('Subaseal', W. Freeman, Barnsley, Yorkshire), to facilitate gas sampling. The flasks were shaken at $200 \mathrm{rev} . / \mathrm{min}$ at $22{ }^{\circ} \mathrm{C}$. Flasks were sterilized by autoclaving at $15 \mathrm{lb} / \mathrm{in}^{2}$ for $15 \mathrm{~min}$. Bungs and caps were sterilized by soaking in $70 \%$ alcohol (acidified with $0 . \mathrm{I} \mathrm{N}-\mathrm{HCl}$ ) overnight and leaving to dry in a sterile cabinet for $2 \mathrm{~h}$.

Growth in chemostat. A 3.81 fermenter, working volume 3.01 (L. H. Engineering Ltd, Stoke Poges, Buckinghamshire) was used, which was especially suitable for the cultivation of moulds. A similar version has been described by Rowley \& Bull (1973). The stirring rate using a 6-bladed paddle stirrer was $1000 \mathrm{rev} . / \mathrm{min}$. Temperature was controlled at $25^{\circ} \mathrm{C}$ and the $\mathrm{pH}$ was maintained at 6.6 by the automatic addition of $2 \mathrm{~N}-\mathrm{HCl}$ and $2 \mathrm{~N}-\mathrm{KOH}$. Foaming was prevented by automatic addition of Silicone DC Antifoam RD Emulsion (Hopkin \& Williams, Romford, Essex) at $0.1 \mathrm{ml} / \mathrm{h}$. Dilution (growth) rate was $0.03 \mathrm{~h}^{\mathbf{- 1}}$. Dissolved-oxygen tension was monitored and controlled with a Mackereth electrode and proportional controller by the method described by Harper \& Lynch (1973). The carrier-gas flow rate of nitrogen used was $500 \mathrm{ml} / \mathrm{min}$. When no oxygen control was used, air at a flow rate of $500 \mathrm{ml} / \mathrm{min}$ was sufficient to give a dissolved-oxygen tension of 80 to $95 \%$ of air saturation when monitored with the oxygen electrode.

The overflow tube from the fermenter was a common effluent for medium and gas. A supplementary effluent pipe from the fermenter headplate was fitted with a pressure-release valve $\left(5 \mathrm{lb} / \mathrm{in}^{2}\right)$. The fermenter vessel and $\mathrm{pH}$ electrode were sterilized by autoclaving, whilst the oxygen electrode was surface sterilized as described for the bungs and caps.

Steady states were defined on the basis of the stability of dry weight and ethylene production over $48 \mathrm{~h}$.

Assay of ethylene. One $\mathrm{ml}$ gas samples were withdrawn from the sealed flasks and analysed with a gas chromatograph (Pye 104, Pye Unicam Ltd, Cambridge) with a $\mathrm{I} \cdot 5 \mathrm{~m} \times 6 \mathrm{~mm}$ alumina column operated isothermally at $\mathrm{I} 10^{\circ} \mathrm{C}$, with nitrogen as carrier gas and a flameionization detector. The alumina was partially deactivated by treatment with sodium iodide. The limit of detection was $0.0 \mathrm{I}$ p.p.m. in a $\mathrm{I} \mathrm{ml}$ gas sample. To facilitate analysis of a large number of samples, an automatic injection device was often used (Smith \& Harris, 1970; Smith \& Dowdell, I973).

As the concentrations of ethylene in the fermenter effluent gas were much lower than in the flask cultures, the ethylene produced was absorbed and concentrated by using a method similar to that of Young, Pratt \& Biale (1952). The effluent was passed through a sparger 
placed into a tube containing a solution of $0.25 \mathrm{M}$-mercuric perchlorate in $2 \mathrm{M}$-perchloric acid ( $15 \mathrm{ml}$ ) which was kept below $5^{\circ} \mathrm{C}$. The gas sample was collected over a period of Io min. Ethylene was regenerated from the perchlorate solution by the addition of an equal volume of $4 \mathrm{M}$-lithium chloride and measured by gas chromatography as above. The overflow pipe was closed during gas sampling and samples taken from the headplate effluent, because otherwise ethylene produced by organisms in the overflow reservoir would have been carried into the gas-sampling stream.

Non-biological production of ethylene. It is well known that rubber and plastics may release ethylene when they are sterilized by heat or irradiation (Jacobsen \& McGlasson, I970; Kavanagh \& Postgate, 1970; Pritchard \& Ross, 1972; Thake \& Rawle, 1972). Consequently, to avoid ethylene release by the rubber bungs, they were sterilized in alcohol as indicated above. Before the start of each fermenter experiment, when the vessel contained sterile medium, the background level of ethylene was assayed. Although none was produced by the vessel, a small amount of ethylene was present in the mercuric perchlorate solution, presumably absorbed from the atmosphere, and this was deducted from the amounts found in the fermentations. When using plastic disposable syringes for gas sampling they were flushed out before use.

It has also been reported that ethylene can be absorbed by rubber (Kavanagh \& Postgate, I970) but in a flask experiment using sterile medium with an atmosphere of 6.I p.p.m. ethylene in air we could detect no losses. However, there was an II.5: I partitioning of ethylene between the gas and liquid phases.

Assay of oxygen and carbon dioxide. Oxygen and carbon dioxide were analysed by gas chromatography by the automated procedure which has been described by Smith \& Dowdell (I973). The column used to separate oxygen was $3 \mathrm{~m} \times 3 \mathrm{~mm}$, packed with $60-85 \mathrm{mesh}$ molecular sieve $5 \mathrm{~A}$, and connected to a hot-wire katharometer. A column of the same dimensions, packed with 50-80 mesh Porapak $Q$ and connected to a thermisior katharometer, was used to separate carbon dioxide. The instrument was a modified Pye Model $R$ and the carrier gas used was helium for both columns.

Assay of methionine and glucose. Methionine was estimated colorimetrically with ninhydrin by using an automated system (Technicon Ltd, Basingstoke, Hampshire). A Technicon automatic amino-acid analyser showed methionine to be the only amino acid present in the medium after growth ceased. Glucose was estimated as total monosaccharide with $m$-aminophenol by a method based on that of Ek \& Hultman (1958), automated for use with a Technicon auto-analyser system.

Soil experiment. Soil (I00 g) from which Mucor hiemalis has been isolated (Lynch, 1972) was added to a flask (capacity $325 \mathrm{ml})$. Glucose $(0.5 \mathrm{~g})$ and methionine $(0.5 \mathrm{~g})$ were added as a solution in water $(50 \mathrm{ml})$. The incubation temperature was $20^{\circ} \mathrm{C}$.

\section{RESULTS}

\section{Substrates required for ethylene biosynthesis}

From a range of compounds tested, only methionine and ethionine, in combination with glucose, induced ethylene formation in Mucor hiemalis (Table I). The growth curve and production of ethylene from methionine and glucose in sealed flasks in shown in Fig. I. Ethylene production usually followed the general pattern indicated but there was considerable variation between experiments in the amount of ethylene produced (in the range $0 \cdot \mathrm{I}$ to $\mathrm{I} 0 \mathrm{nmol} \mathrm{ml} \mathrm{m}^{-1} 48 \mathrm{~h}^{-1}$ ), although there was good replication between flasks of the same treatment (at least 4 replicates) in each experiment. 
Table I. Substrate requirements for ethylene formation by Mucor hiemalis in sealed flasks All substrates at $0.5 \mathrm{~g} / 100 \mathrm{ml}$ were added with glucose at $0.5 \mathrm{~g} / 100 \mathrm{ml}$.

Substrate tested
DL-Methionine
L-Methionine
DL-Ethionine
DL-Norleucine
DL-Lysine
DL-Serine
DL- $\beta$-Alanine
DL-Cysteine HCl
Glutamate
Acetate
Citrate
Succinate
Pyruvate
Ethanol

\begin{tabular}{|c|}
\hline $\begin{array}{l}\text { Organism dry weight } \\
(\mathrm{mg} / \mathrm{1} 00 \mathrm{ml})\end{array}$ \\
\hline 160 \\
\hline I 60 \\
\hline 140 \\
\hline 170 \\
\hline I 60 \\
\hline 160 \\
\hline 160 \\
\hline 10 \\
\hline 160 \\
\hline 50 \\
\hline 50 \\
\hline 60 \\
\hline 60 \\
\hline 30 \\
\hline
\end{tabular}

Ethylene
production

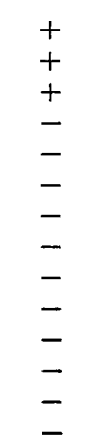

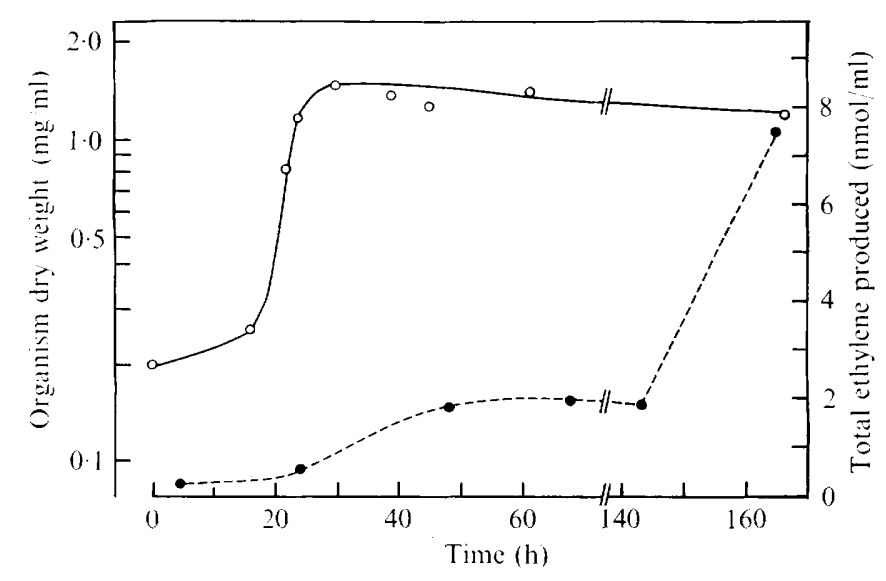

Fig. I. Growth curve and ethylene production by Mucor hiemalis. $\bigcirc-O$, Dry weight;

- - - ethylene.

In each flask experiment the maximum dry weight was reached after approximately $30 \mathrm{~h}$ and at that time glucose became exhausted whilst about $80 \%$ of the methionine remained (Fig. 2). The concentration of oxygen in the gas phase was also greatly reduced after $30 \mathrm{~h}$ with a concomitant accumulation of carbon dioxide (Fig. 3). However, ethylene was still being formed after active growth ceased. During the death phase, there was a peak in ethylene production, but the magnitude and time of occurrence of this was widely variable between experiments. Under the ill-defined physical conditions of the sealed flask, which has the restriction of no free gas exchange to the system in addition to the usual limitations of batch cultures, it is perhaps not surprising to find such inter-experimental variation. Using the chemostat we have observed no such variations and under the given standard conditions, ethylene production has been constant in all fermentations over a period of 12 months.

Mucor hiemalis could utilize methionine as its sole carbon source in sealed flasks but the growth rate was very slow (about I/Io of that on glucose and methionine) and the amount of ethylene produced per unit weight of organism was also considerably reduced (Table 2). 


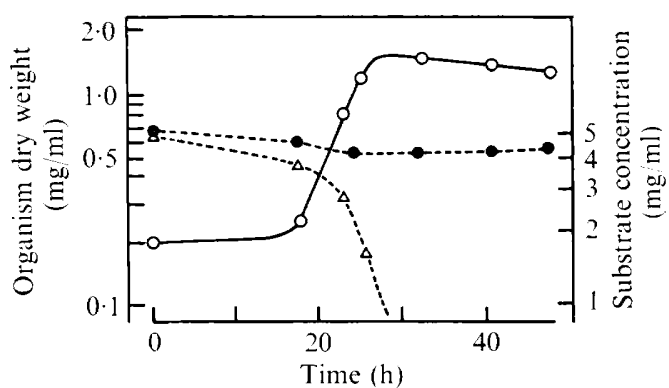

Fig. 2

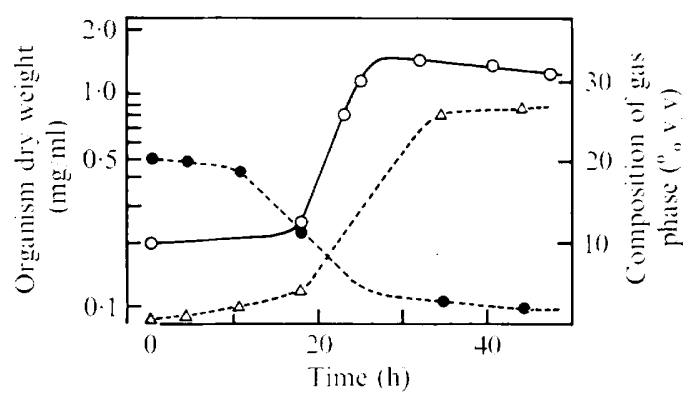

Fig. 3

Fig. 2. Growth curve and carbon substrate utilization for Mucor hiemalis in sealed flask cultures. $\bigcirc-\bigcirc$, Dry weight; --- - , methionine; $\triangle--\triangle$, glucose.

Fig. 3. Growth and respiration of Mucor hiemalis in sealed flask cultures. $\bigcirc-\bigcirc$, Dry weight; -.. oxygen; $\triangle-. \triangle$, carbon dioxide.

Table 2. Effect of carbon source on ethylene formation by Mucor hiemalis in sealed flasks

Each substrate was added at $0.5 \mathrm{~g} / 100 \mathrm{ml}$.

\begin{tabular}{lccc} 
& \multicolumn{3}{c}{$\begin{array}{c}\text { Ethylene production } \\
\text { (nmol/g dry wt of organism) }\end{array}$} \\
Substrate & $\overbrace{3 \text { days }}$ & I2 days & 20 days \\
Glucose and methionine & 3000 & 3680 & 9300 \\
Methionine & 0 & 430 & 2400 \\
Glucose & 0 & 0 & 0
\end{tabular}

Growth and ethylene production by $M$. hiemalis was unaffected when the concentration of methionine was reduced to $\mathrm{I} g / \mathrm{l}$ in flasks and therefore this concentration was used in the chemostat studies.

It was found that the turbidimetric method of estimation of growth reported by Trinci (1972) could be used during the logarithmic growth of the organism but 'clumping' at the end of active growth limited its use after that.

\section{The effect of oxygen on growth and ethylene production}

Smith \& Restall (I97I) found that oxygen inhibited ethylene production in the soil. Consequently in our initial studies, Mucor hiemalis was grown in the glucose-methionine medium with the oxygen-limiting conditions of sealed flasks, which were much more convenient for ethylene assays than open flasks. That oxygen was a growth-limiting factor under these conditions is clear from Table 3; it can be seen that the growth yield of $M$. hiemalis from glucose was increased when the gas space relative to the medium volume in the flask was increased, or when the rubber bung was replaced with a cotton wool plug to allow free gas exchange. The results cannot be explained in terms of a switch to methionine as the energy-yielding substrate, because methionine uptake per unit weight of organism was the same in open and sealed flasks. These different conditions of oxygen supply had little effect on the maximum specific growth rate of $0.2 \mathrm{I} \mathrm{h}^{-1}$, which exceeded $0.099 \mathrm{~h}^{-1}$ (Trinci, I969) and $0.17 \mathrm{~h}^{-1}$ (Trinci, I972) previously reported for $M$. hiemalis growing in defined media; the higher growth yields with increased oxygen supply were the result of the organism grow- 
Table 3. Growth yields from glucose of Mucor hiemalis grown in sealed and open flasks

Volume of medium
$\left(\begin{array}{c}\text { (ml) } \\ 100 \\ 100 \\ 25 \\ 25\end{array}\right.$

$\begin{array}{cc}\begin{array}{c}\text { Type of } \\ \text { flask closure }\end{array} & \begin{array}{c}\text { (g dry wt of organism/g } \\ \text { glucose) }\end{array} \\ \text { Rubber bung } & 0.23 \\ \text { Cotton wool } & 0.42 \\ \text { Rubber bung } & 0.39 \\ \text { Cotton wool } & 0.47\end{array}$

The total flask volume in each case was $340 \mathrm{ml}$. For each treatment, the number of replicates was 6 and the standard error was $\pm 0.0 \mathrm{r}$.

Table 4. Ethylene production by sealed flask cultures on Mucor hiemalis when incubated in atmospheres with various initial amounts of oxygen

All flasks were incubated for $48 \mathrm{~h}$.

Initial
percentage
of oxygen

I

5

2 I

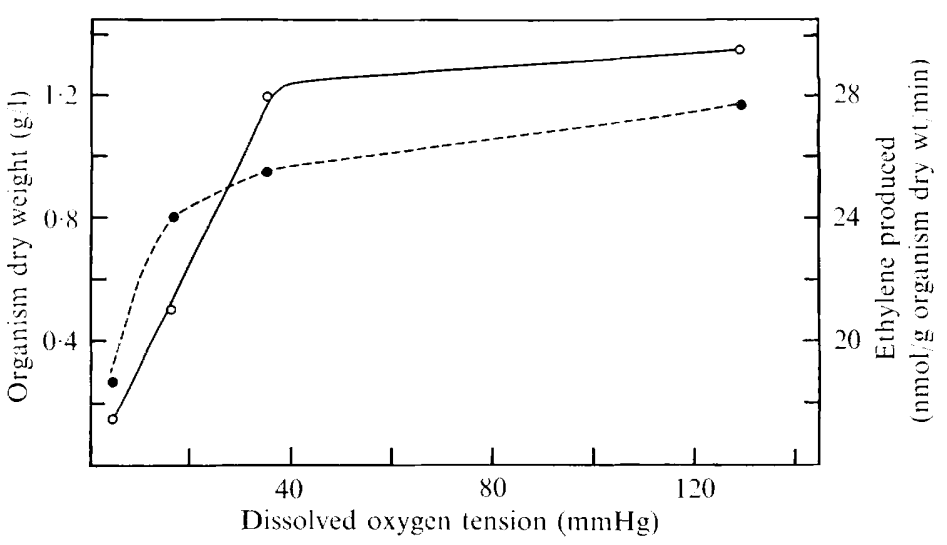

Fig. 4. Effect of oxygen on organism concentration and ethylene production by steady-state cultures of Mucor hiemalis. $\bigcirc-\bigcirc$, Dry weight;

\begin{tabular}{|c|c|}
\hline $\begin{array}{l}\text { Total } \\
(\mathrm{nmol})\end{array}$ & $\begin{array}{l}\text { Per unit dry wt of organism } \\
\qquad(\mathrm{nmol} / \mathrm{g})\end{array}$ \\
\hline 9 & 1000 \\
\hline 65 & 1970 \\
\hline 225 & 2730 \\
\hline
\end{tabular}

ing for a longer period of time. Moreover, when $M$. hiemalis was incubated in sealed flasks with various initial concentrations of oxygen, both growth and ethylene production per unit weight of organisms were promoted by oxygen (Table 4 ). This oxygen effect was confirmed in the more controlled conditions of the chemostat (Fig. 4).

The present findings which show that the presence of oxygen favours ethylene formation were obtained under laboratory conditions where there was an ample supply of substrates available to the organism. This suggests that when Smith \& Restall (197I) showed that the production of ethylene in the soil was inhibited by oxygen, it was due not to a direct effect of oxygen on the organisms which produced ethylene but to inadequate substrates being available to them under aerobic soil conditions. This supposition was encouraged by the 


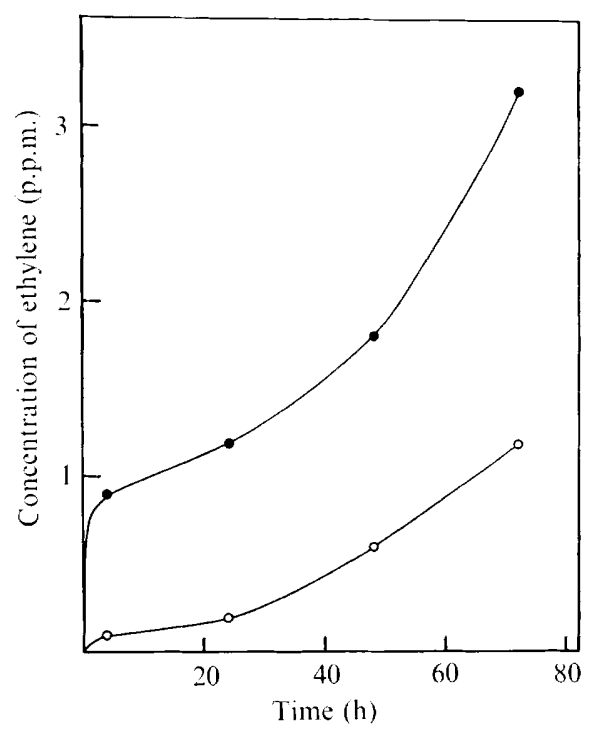

Fig. 5. Effect of oxygen on ethylene production by soil to which substrates have been added at zero time. Suspension and gas phase saturated with air $(O$, aerobic) or nitrogen $(O$, anaerobic).

further observations of Smith \& Restall (I97I) that when soil was kept at field capacity under aerobic conditions, the ability to produce ethylene decreased. Accordingly, we investigated the effect of adding glucose and methionine to soil in sealed flasks. Immediately after the addition, more ethylene was formed under aerobic than anaerobic conditions; however, a few hours after the start of the experiment, when oxygen in the aerobicallysealed flask had become depleted, the rate at which ethylene was produced decreased to a level comparable to that in the initially anaerobic flasks (Fig. 5). The most likely explanation for the production of ethylene in natural soils being favoured by low oxygen tensions thus seems to be that substrates necessary for its production are mobilized under these conditions.

\section{DISCUSSION}

Methionine might not be available to Mucor hiemalis in the soil as the free amino acid but would probably be present as the peptide. In the soil from which $M$. hiemalis was isolated, we have found methionine only after acid hydrolysis. It is thus interesting that peptides containing methionine have proved to be more efficient precursors of ethylene than methionine itself in model systems ( $\mathrm{Ku} \&$ Leopold, 1970). It might be argued that considering the low efficiency of conversion of methionine to ethylene, methionine pools in the soil, even as the peptide, would be too low to account for the ethylene concentrations of Io p.p.m. sometimes found in the soil atmosphere. However, Baur \& Yang (1972) have shown that the $\left[\mathrm{CH}_{3} \mathrm{~S}\right]$ group from methionine can be re-cycled through other sulphurcontaining amino acids to form more methionine.

Different crop residues would lead to different amounts of carbohydrate and protein in the soil and hence the cropping history of a field is likely to be important in determining the ethylene-producing capacity of a soil. Some preliminary results add support to this hypothesis (Lynch \& Harper, 1973). 
Whereas it seems most likely to us that the effect of 'anaerobic' (low oxygen) conditions on ethylene production in the soil could be explained as substrate mobilization, it should also be remembered that Mucor hiemalis can grow at very low oxygen tensions, and under the anaerobic soil state it might experience less competition for substrates from obligately aerobic micro-organisms. A further alternative explanation is that ethylene metabolism, which has been reported in soils (Abeles, Craker, Forrence \& Leather, I971), is favoured aerobically, so that less ethylene accumulation would be expected in aerobic soils.

It is evident that more ethylene is formed in the 'open' system of the chemostat than in the 'closed' system of the sealed flask. Smith \& Restall (I97I) concluded that in a 'closed' soil system, a volatile inhibitor of ethylene formation accumulated. A similar phenomenon might occur with the pure microbial system.

Ethylene is known to have many effects on plants, but little has been reported of its effects on micro-organisms. However, volatile unsaturated hydrocarbons have been implicated as a possible causative agent of soil fungistasis (Balis \& Kouyeas, 1968; Forsyth, I955; Watson \& Ford, 1972); hence ethylene might be responsible for this important soil condition. Ethylene has also been reported to inhibit root nodulation (Grobbelaar, Clarke \& Hough, 1970; 1971).

Although many studies have been undertaken to determine the biochemical pathway from methionine to ethylene in plants, it remains an enigma (Lieberman \& Kunishi, I97I; Phan, I97I). The micro-organism provides an alternative system in which to study the conversion and this is currently under investigation (Lynch, I973).

We are grateful to Miss J. M. Webb for her excellent technical assistance.

\section{REFERENCES}

Abeles, F. B., Craker, L. E., Forrence, L. E. \& Leather, G. R. (197I). Fate of air pollutants: removal of ethylene, sulfur dioxide, and nitrogen dioxide by soil. Science, New York 173, 914-9r6.

Balis, C. \& Kouyeas, V. (1968). Volatile inhibitors involved in soil mycostasis. Annales de l'Institut phytopathologique Benaki NS 8, I45-I49.

BAUR, A. H. \& YANG, S. F. (1972). Methionine metabolism in apple tissue in relation to ethylene biosynthesis. Phytochemistry Ir, 3207-32I4.

Domsch, K. H. \& Gams, W. (1972). Fungi in Agricultural Soils. London: Longman.

Dowdell, R. J., Smith, K. A., Crees, R. \& Restall, S. W. F. (1972). Field studies of ethylene in the soil atmosphere - equipment and preliminary results. Soil Biology and Biochemistry 4, 325-33I.

Eк, J. \& Hultman, E. (1958). Determination of glucose and laevulose in body fluids. Nature, London 18r, $780-781$.

ForsYTH, F. R. (1955). The nature of the inhibiting substance emitted by germinating urediospores of Puccina graminis var. tritici. Canadian Journal of Botany 33, 363-373.

Freebairn, H. T. \& Buddenhagen, I. W. (1964). Ethylene production by Pseudomonas solanacearum. Nature, London 202, 31 3-3I4.

Grobbelaar, N., Clarke, B. \& Hough, M. C. (1970). The inhibition of root nodulation by ethylene. Agroplantae 2, 8I-82.

GrobbelaAR, N., Clarke, B. \& Hough, M. C. (1971). The nodulation and nitrogen fixation of isolated roots of Phaseolus vulgaris L. III. The effect of carbon dioxide and ethylene. Plant and Soil (special volume), 215-223.

HaLl, W. C. (195I). Studies on the origin of ethylene from plant tissues. Botanical Gazette 113, 55-65.

HARPER, S. H. T. \& LYNCH, J. M. (1973). A modified system for the automatic control of dissolved oxygen concentration in stirred microbial cultures. Laboratory Practice (in the Press).

Ilag, L. \& Curtis, R. W. (1968). Production of ethylene by fungi. Science, New York 159, 1357-1 358.

JaCobsen, J. V. \& MCGLASSON, W. B. (1970). Ethylene production by autoclaved rubber injection caps used in biological systems. Plant Physiology 45, 631. 
Jacobsen, J. V. \& Wang, C. H. (1968). The biogenesis of ethylene in Penicillium digitatum. Plant Physiology 43. $1959-1966$.

Kavanagh, E. P. \& Postgate, J. R. (1970). Absorption and release of hydrocarbons by rubber closures: a source of error in some biological assays. Laboratory Practice 19, 159-160.

Ku, H. S. \& LeOpold, A. C. (1970). Ethylene formation from peptides of methionine. Biochemical and Biophysical Research Communications 41, I $155-1160$.

Lieberman, M. \& Kunishi, A. (I97 I). Synthesis and biosynthesis of ethylene. HortScience 6, 353-392.

Lieberman, M., Kunishi, A. T., Mapson, L. W. \& Wardale, D. A. (I965). Ethylene production from methionine. Biochemical Journal 97, 449-459.

Lieberman, M., Kunishi, A. T., Mapson, L. W. \& Wardale, D. A. (i966). Stimulation of ethylene production in apple tissue slices by methionine. Plant Physiology 41, 376-382.

LYNCH, J. M. (1972). Identification of substrates and isolation of micro-organisms responsible for ethylene production in the soil. Nature, London 240, 45-46.

LyNCH, J. M. (1973). Extracellular ethylene formation by Mucor hiemalis. Journal of General Microbiology 77, iv.

Lynch, J. M. \& HARPER, S. H. T. (1973). The microbiological formation of ethylene in the soil. Agricultural Research Council Letcombe Laboratory Annual Report 1972, pp. 24-26.

Phan, C. T. (1960). Nouvelles observations sur les substances capables de stimuler la formation d'éthylène par le Penicillium digitatum Sacc. Compte rendu hebdomadaire des séances de l'Académie des Sciences 251, 122-1 24.

Phan, C. T. (197I). L'Éthylène, Métabolisme et Activité Métabolique. Paris: Masson et Cie.

Pritchard. D. W. \& Ross, A. F. (1972). Limitations of some methods for ethylene collection from plant leaf tissue. Plant Physiology 49, S64.

Rowley, B. I. \& Bull, A. T. (1973). Chemostat for the cultivation of moulds. Laboratory Practice 22, $286-289$.

Smith, K. A. \& Dowdell, R. J. (I973). Gas chromatographic analysis of the soil atmosphere: Automatic analysis of gas samples for $\mathrm{O}_{2}, \mathrm{~N}_{2}, \mathrm{Ar}, \mathrm{CO}_{2}, \mathrm{~N}_{2} \mathrm{O}$ and $\mathrm{C}_{1}-\mathrm{C}_{4}$ hydrocarbons. Journal of Chromatographic Science (in the Press).

SmIth, K. A. \& Harris, W. (1970). An automatic device for injection of gas samples into a gas chromatograph. Journal of Chromatography 53, 358-362.

Smith, K. A. \& Restall, S. W. F. (197I). The occurrence of ethylene in anaerobic soil. Journal of Soil Science 22, 430-443.

Smith, K. A. \& Robertson, P. D. (197I). Effect of ethylene on root extension of cereals. Nature, London 234, $148-149$.

Smith, K. A. \& Russell, R.S. (1969). Occurrence of ethylene, and its significance, in anaerobic soil. Nature, London 222, 769-77I.

Swanson, B. T., Wilkins, H. F. \& KENNEDY, B. (1972). Factors influencing endogenous biosynthesis of ethylene by pathogenic bacterium Pseudomonas solanacearum 25. HortScience 7, 26.

THAKe, B. \& RAWLE, P. R. (1972). Non-biological production of ethylene in the acetylene reduction assay for nitrogenase. Archiv für Mikrobiologie 85, 39-43.

Trinci, A. P. J. (1969). A kinetic study of the growth of Aspergillus nidulans and other fungi. Journal of General Microbiology 57, I I-24.

TrINCI, A. P. J. (1972). Culture turbidity as a measure of mould growth. Transactions of the British Mycological Society 58, 467-473.

Wang, C. H., Persyn, A. \& Krackov, J. (1962). Role of the Krebs cycle in ethylene biosynthesis. Nature, London 195, I306-1 308.

WATSON, A. G. \& Ford, E. J. (1972). Soil fungistasis - a reappraisal. Annual Review of Phytopathology I0, 327-348.

Young, R. E., Pratt, H. K. \& Biale, J. B. (1952). Manometric determination of low concentrations of ethylene. Analytical Chemistry 24, 55 I-555. 